\title{
Suppressive effects of liquid crystal compounds on the growth of U937 human leukemic monocyte lymphoma cells
}

\author{
Junya Ishikawa', Yuuka Takahashi², Masaharu Hazawa', Yukako Fukushi², Atsushi Yoshizawa ${ }^{2}$ and \\ Ikuo Kashiwakura ${ }^{1 *}$
}

\begin{abstract}
Background: The aim of this study was to evaluate the biological and pharmaceutical activities of 14 amphiphilic liquid-crystalline compounds (LCs), i.e, phenylpyrimidine derivatives possessing D-glucamine and cyanobiphenyl derivatives with a terminal hydroxyl unit.

Results: The cytotoxic properties of the LCs on the cell growth, cell cycle distribution, and cell signaling pathway of U937 human leukemic monocyte lymphoma cells were assessed by flow cytometry and western blot analysis. Some LCs showed cytostatic effects, suppressing cell growth via S-phase arrest and without apoptosis in U937 cells. To investigate the mechanisms of the LC-induced S-phase arrest, proteins relevant to cell cycle regulation were investigated by western blot analysis. The rate of LC-induced S-phase arrest was congruent with the decreased expression of MCM2, cyclin A, cyclin B, CDK2, phospho-CDK1 and Cdc25C. Observed changes in cell cycle distribution by LC treated might be caused by insufficient preparation for G2/M transition. Considering the structure of the LCS, the rod-like molecules displaying cytotoxicity against U937 cells possessed flexible spacers with no bulky polar group attached via the flexible spacer.
\end{abstract}

Conclusions: Our results revealed that some LCs showed cytotoxic properties against non-solid type tumor human leukemic cells via LC-induced S-phase arrest and decreasing expression of several cell cycle related proteins.

Keywords: Liquid-crystalline compound, U937 human leukemic monocyte lymphoma cells, S-phase arrest

\section{Background}

Chemotherapy can regulate the uncontrolled proliferation of abnormal cancer cells by using various types of drugs. The majority of chemotherapeutic drugs can be divided into categories, including the alkylating agents, antimetabolites, anthracyclines, plant alkaloids, topoisomerase inhibitors, monoclonal antibodies, and other antitumor agents [1-7]. Although several types of chemotherapeutic agents have been developed recently, such as molecular targetting drugs, the tyrosine kinase inhibitor Imatinib, only few drugs may result in complete recovery of cancer patients. Therefore, it is essential to develop novel drugs for cancer treatment.

\footnotetext{
* Correspondence: ikashi@cc.hirosaki-u.ac.jp

'Department of Radiological Life Sciences, Hirosaki University Graduate

School of Health Sciences, 66-1 Hon-cho, 036-8203, Aomori Hirosaki, Japan

Full list of author information is available at the end of the article
}

Liquid-crystalline compounds (LCs) are widely used in display media in televisions and personal computers. LCs are classified into various categories on the basis of their structural characteristics. One of the principal compounds is an amphiphilic compound, consisting of hydrophobic and hydrophilic components. Amphiphilic liquid crystals are thought to have structural affinity to the cell membranes, which are lamellar bilayer mesophases of phospholipids, glycolipids, and cholesterol. Therefore, some lyotropic LCs displaying a structural affinity to the cell membranes have been applied for the development of novel drug delivery systems [3]. Although these amphiphilic LCs seem promising for biological applications, the pharmacological properties of LCs are not well understood, and therefore, must be elucidated.

\section{C) Biomed Central}

(c) 2012 Ishikawa et al; licensee BioMed Central Ltd. This is an Open Access article distributed under the terms of the Creative Commons Attribution License (http://creativecommons.org/licenses/by/2.0), which permits unrestricted use, distribution, and reproduction in any medium, provided the original work is properly cited. 
Our recent reports demonstrated that some lyotropic LC materials, namely, the phenylpyrimidine and cyanobiphenyl derivatives, showed cytostatic effects on the growth of solid tumor A549 human lung cancer cells, causing G1-phase arrest in cells. One of the phenylpyrimidine derivatives inhibited A549 growth without any toxicity to normal fibroblasts $[8,9]$. However, it is not yet known whether these LCs have cytotoxic properties against non-solid type tumor leukemic cells that are commonly treated by chemotherapy. To clarify this issue, we investigated the cytotoxic properties of 14 amphiphilic LCs against the human leukemic monocyte lymphoma cell line U937.

\section{Results}

Screening of LCs with respect to the cytotoxicity against U937 cells

The effect of each compound $(10 \mu \mathrm{M})$ on the growth of the U937 cells was tested to investigate the cytotoxic properties of the LCs shown in Table 1. Compound \#8, which contains a cyanobiphenyl in its central position, and compound $\# 13$, which contains a phenylpyrimidine, showed the maximum suppressive effect among all the compounds tested herein (Figure 1). Therefore, subsequent studies were performed using compounds \#8 and $\# 13$ to characterize their suppressive mechanisms on the growth of U937 cells.

To determine the growth inhibitory profiles for \#8 and \#13 on U937 cells, proliferation assays were performed at various time points and concentrations. Both compounds \#8 and \#13 exhibited cytotoxic properties in a time-dependent manner (Figure $2 \mathrm{~A}$ ). The $\mathrm{IC}_{50}$ values of compounds \#8 and \#13 were 6.8 and $6.3 \mu \mathrm{M}$, respectively (Figures 2B, C). Therefore, subsequent experiments were mainly performed using the determined $\mathrm{IC}_{50}$ values.

\section{Effects of LCs on apoptosis and cell cycle distribution}

During the early stages of apoptosis, translocation of phosphatidylserine (PS) to the cell surface is a key signal in the apoptotic pathway. Annexin $\mathrm{V}$ is a $\mathrm{Ca}^{2+}$-dependent phospholipid-binding protein with high affinity for PS [10]. Therefore, to elucidate whether apoptotic induction is involved in the cytotoxic property of LCs, cells were analyzed by flow cytometry using Annexin VFITC and PI staining (Figure 3). Although each of the LCs induced $50 \%$ growth suppression, indiscernible changes were observed between the control and LCtreated groups in each fraction (each Annexin V-positive/PI-negative fraction of control, \#8 and \#13 was 1.5\% and $1.8 \%$, respectively). These data indicate that the cytotoxic properties of LCs are not related to apoptotic and necrotic induction of cell death.
Table 1 Structure of liquid crystalline compounds

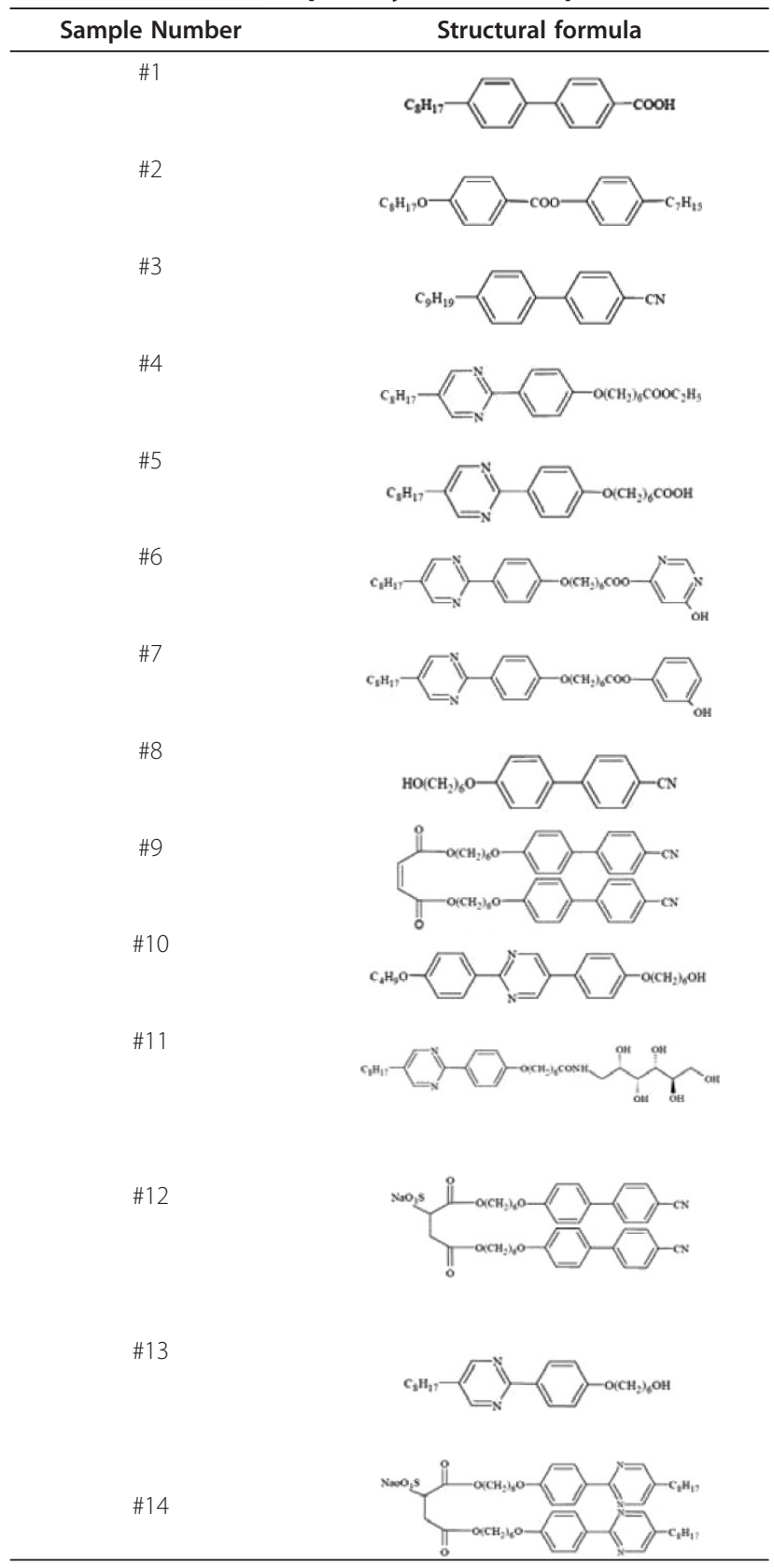

S-phase arrest by LCs in the cell cycle of U937 cells

Since anti-tumor drugs usually affect the cell cycle distribution [11], the cell cycle distribution in U937 cells treated with LCs was analyzed by flow cytometry. As shown in Figure 4A, no modification of the cell cycle distribution was observed in LCs-treated cells compared to the controls at $3 \mathrm{~h}$. However, LCs significantly induced the S-phase population at 6 and $12 \mathrm{~h}$ (Figure 4B). These data indicated that LCs induced S-phase arrest in U937 cells. 


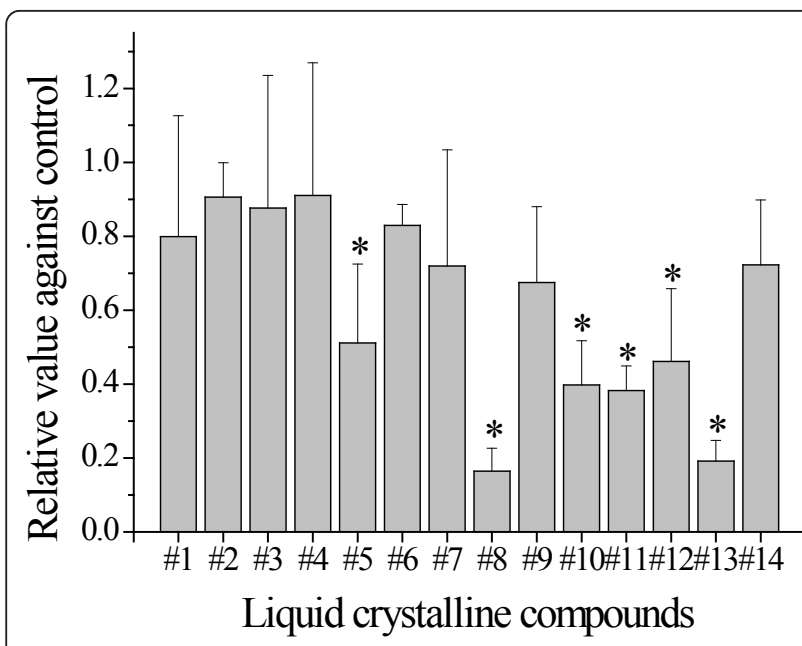

Figure 1 Screening of LCs with respect to the cytotoxicity against U937 cells. Effects of liquid crystalline compounds on the growth of theU937 human leukemic monocyte lymphoma cell line. The cells were cultured in liquid medium containing $10 \mu \mathrm{M}$ of each compound for 48 h. ${ }^{*} p<0.05$ using Student's $t$-test.

Inhibitory regulation of several proteins expression related to cell cycle progression by LCs in U937 cells

To investigate the mechanism of S-phase arrest induction by LCs, proteins relevant to cell cycle regulation were evaluated by western blot analysis of U937 cells

[A]

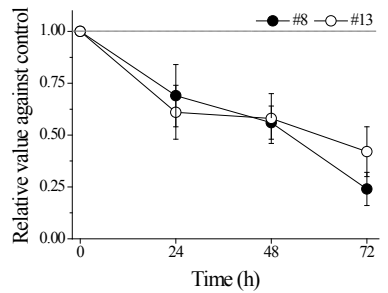

$[\mathrm{B}]$
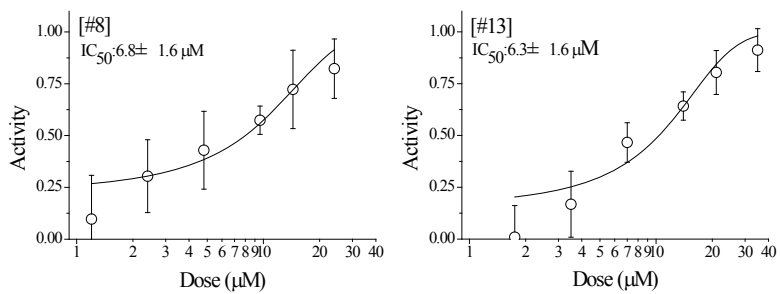

Figure 2 Suppressive effects of the liquid crystalline compounds \#8 and \#13 on the growth of U937 cells. [A] Cells were treated with 6-7 $\mu \mathrm{M}$ liquid crystalline compounds or DMSO for the indicated periods. [B] The dose response curves of U937 cells to liquid crystalline compounds. Activity shows growth inhibition rate. The $I_{50}$ values were determined using the Boltzmann functions. Values are the mean \pm standard deviation (S.D.) value of more than 3 separate experiments in duplicate wells. treated with compounds \#8 and \#13 (Figure 5). CDK2 and cyclin $\mathrm{E}$ are known to regulate progression through G1/S transition [12,13], and MCM2 is required in the acquisition of DNA replication fork $[14,15]$. Cyclin A is required for both progression $S$ phase and $M$ phase [16]. Activation of CDK1 regulate entry into mitosis, and is controlled at several steps including cyclin B binding and dephosphorylation of CDK1 at Thr 14/ Tyr15 by Cdc25C phosphatase [17-19]. As shown in Figure 5 , the expression of MCM2 was decreased by LC treatment at $1 \mathrm{~h}$, and the expression of cyclin $\mathrm{A}$, cyclin $\mathrm{E}, \mathrm{CDK} 2$ were decreased by $\mathrm{LC}$ treatment at 1-6 h. In addition, the expression of $\mathrm{Cdc} 25 \mathrm{C}$ was decreased by $\mathrm{LC}$ treatment at $6 \mathrm{~h}$, and the expression of phosphoCDK1 (Tyr 15) was decreased by LC treatment at 1-6 $\mathrm{h}$.

\section{Discussion}

The pharmaceutical activities of 14 amphiphilic LCs were examined in human leukemic monocyte lymphoma U937 cells (Table 1). Some LCs (\#5, \#8, \#10-13) showed cytotoxic properties (Figure 1). Among the LCs tested, compounds \#8 and \#13 showed marked cytotoxicity, and the $\mathrm{IC}_{50}$ values of these compounds were similar (6.8 and $6.3 \mu \mathrm{M}$, respectively) (Figure 2). However, cytotoxic effects by these compounds had no relation to apoptosis induction supported by Annexin V/PI staining analysis (Figure 3). Both compounds were considered to delay $\mathrm{S}$-phase progression in cell cycle, through inhibition of MCM2, cyclin A, cyclin B, CDK2, phosphoCDK1 (Tyr15) and Cdc25C expression (Figures 4, 5).

The cell cycle is a fundamental and ordered event in which DNA replicates, and homologous chromosomes segregate and equally distributed among the daughter cells. Therefore, the oscillation of specific protein expressions is important in cell cycle progression. The tyrosine phosphatase Cdc25C serve as mitotic activator through dephosphorylation of CDK1 at Tyr14/15 and is negatively regulated by phosphorylation at Ser216. Because LCs is considered to prevent S-phase progression through MCM2 inhibition and insufficient cyclin proteins, decreased phospho-CDK1 (Tyr15) might reflect the failure of Tyr 15 phosphorylation by Wee1 in G2 phase. Therefore, majority of CDK1 exist as inactivated form comparing to control and both $\mathrm{Cdc} 25 \mathrm{C}$ and phos-Cdc25C (Ser216) decrease imply mere lack of preparation for cell cycle progression. Similar phenomenon were reported that reducing cyclin A/CDK2 and Cdc25C expressions lead to $\mathrm{S}$ phase arrest in human Lovo colon cancer cells [19].

The cytotoxic property and classes of active compound depend on cell types because compounds cytotoxic to U937 cells (\#5, \#8, \#10-13) are not necessarily cytotoxic to other cell types, lung cancer A549 cells [8]. Compounds \#5, \#10, \#12, and \#13 had little effects 


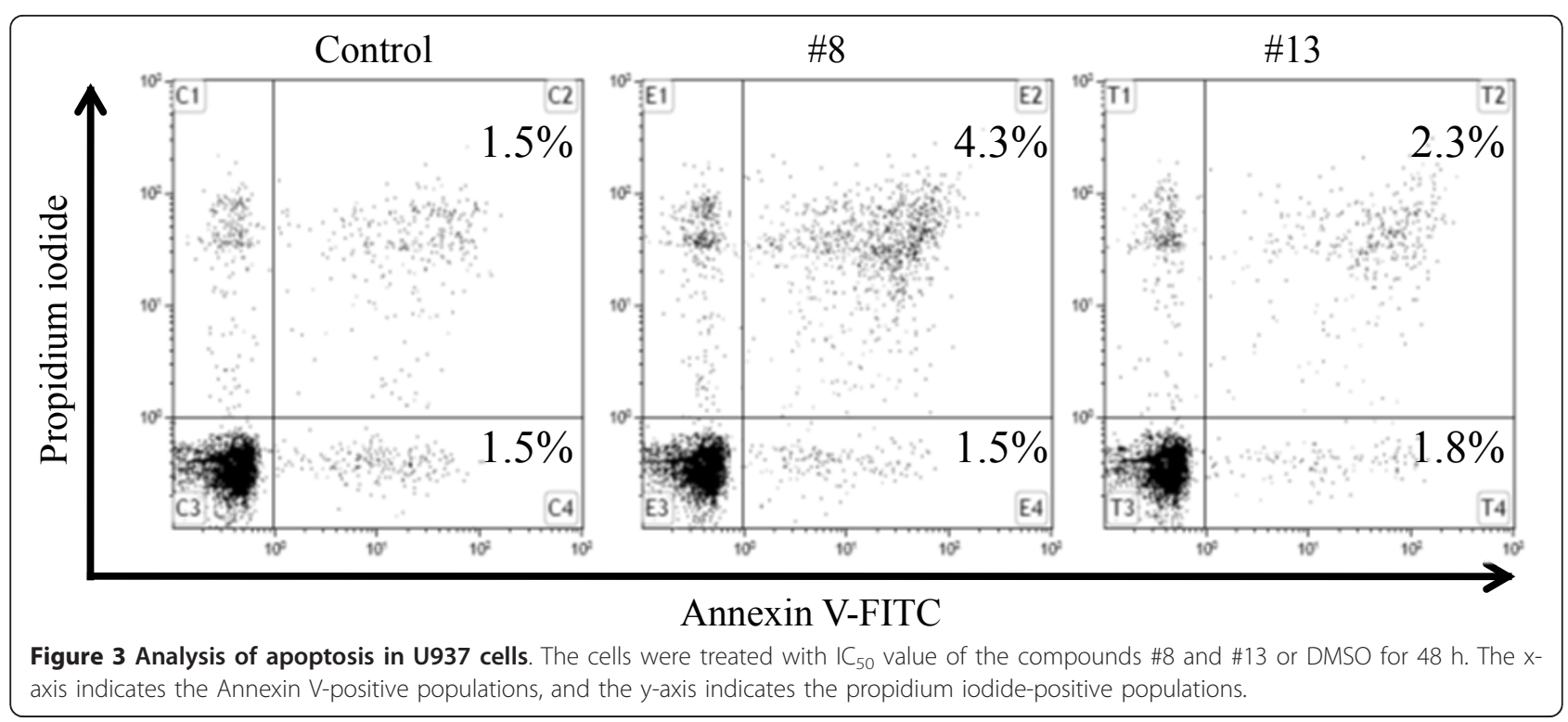

against A549 cells and compound \#8 induced not Sphase arrest observed present study but G1-phase arrest in A549 cells without apoptosis [8]. Nevertheless, apoptosis unrelated toxicity is common feature of compound \#8, which is supporsed torelate with p53 independent mechanism because A549 and U937 cells have valid p53 genomic contexts $[20,21]$. The loss of p53 function generally leads to resistance to chemotherapeutic drugs, tumor malignancy and metastasis [22], therefore, compound $\# 8$ could be an effective drug against a variety of tumors regardless of p53 status.

The structure of LCs may be responsible for the cellspecific cytotoxic effects exerted by the different LCs. For example, \#11, in which D-glucamine and phenylpyrimidine are connected via a flexible spacer, displayed a strong cytotoxic effect against A549 cells, but showed only a moderate cytotoxic effect against U937 cells. Compound \#13, in which D-glucamine was removed from \#11, did not exert cytotoxic effects against A549 cells; however, it showed a strong cytotoxic effect against U937 cells. These results suggest that differences in the molecular structures of the LCs were responsible for the differences in their cell type-specific inhibitory effect. Previously, Takahashi et al. demonstrated that the suppressive effects of cyanobiphenyl derivatives on A549 cells depended on alkyl chain length rather than on the terminal substrate or the position of hydroxyl moieties [8]. Interestingly, both compounds \#8 and \#13, which showed strong cytotoxic effects against U937 cells, possess $-\mathrm{O}\left(\mathrm{CH}_{2}\right)_{6} \mathrm{OH}$ in their structure. Furthermore, the compounds that had cytotoxic activity against U937 cells (\#5, \#8, \#10, \#11, and \#13) were structured as rod-like molecules. These rod-like molecules possess a flexible spacer consisting of an alkyl chain such as
$\left(\mathrm{CH}_{2}\right)_{6}$ and are not attached to a bulky polar group such as $-\mathrm{OH},-\mathrm{CN}$, and $-\mathrm{COOH}$ via this flexible spacer. These structures might play an important role in the cytotoxic effects against U937 by LCs. Further, studies are necessary to elucidate the structure-activity relationships.

It remains unclear how active LC compounds inhibited expression of several cell cycle related proteins. However, LCs clearly suppressed the growth of tumor cells independent of p53. In addition, the cytotoxicity of compound \#8 is enhanced by mixing another LC at an equimolar concentration, which is suspected to result in an antiparallel molecular alignment via a dipole-dipole interaction [23]. Because anti-cancer drugs used at clinical situation remains several problems including pharmacological tolerance and secondary effect, further studies are clearly required to elucidate LC's structural properties and its pharmacological activity.

\section{Conclusion}

In this study, some LCs showed cytostatic effects, suppressing cell growth via S-phase arrest and without apoptosis in U937 cells. Furthermore, LCs clearly suppressed the growth of tumor cells independent of p53. Our results suggest that some LCs possessing cytotoxic properties may be useful for cancer treatments irrespective of their p53 status.

\section{Methods}

\section{Liquid crystal compounds}

Compound \#1 was provided by Midori Kagaku Co., Ltd. (Tokyo, Japan). Compound \#2 was provided by Japan Energy Corporation (Tokyo, Japan) and compound \#3 was purchased from the Kanto Chemical Co., Ltd. 


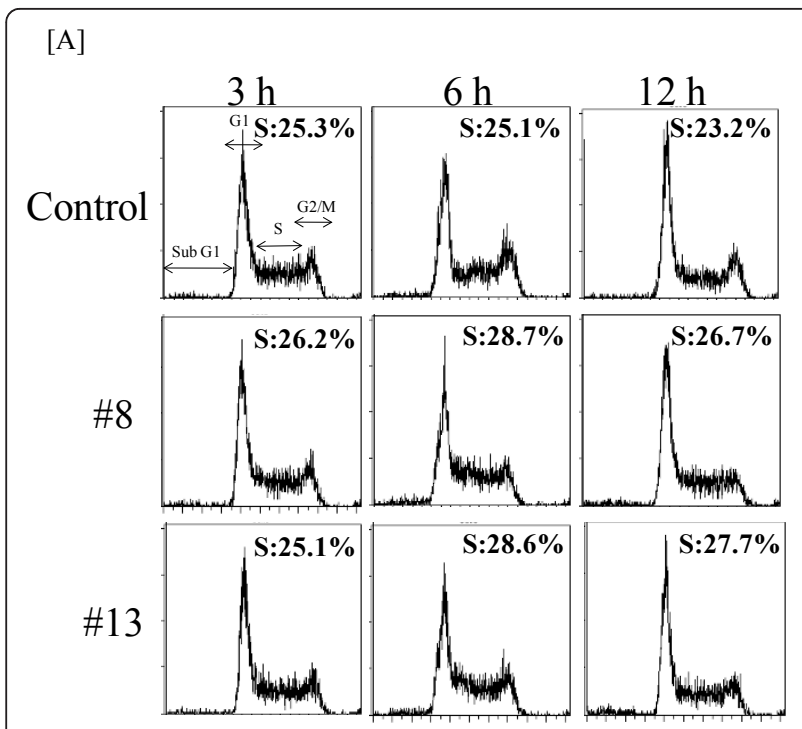

[B]

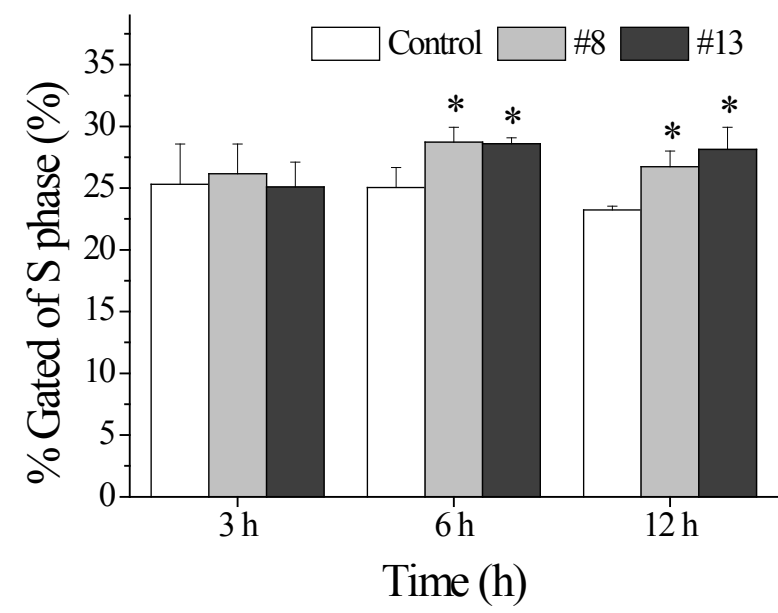

Figure 4 Effect of liquid crystalline compounds on the cell cycle distribution in U937 human leukemic monocyte lymphoma cells. [A] Flow cytometry analysis of U937 cells treated with each compounds for indicated times. Representative cytograms are shown. [B] The rate of S-phase in U937 cells was shown. Values are the mean \pm standard deviation (S.D.) value of at least 3 separate experiments. ${ }^{*} p<0.05$ by Student's $t$-test.

(Tokyo, Japan). The other compounds in Table 1 were synthesized in our laboratory.

Each compound was dissolved in dimethyl sulfoxide (DMSO; Wako, Osaka, Japan) at $0.1 \mathrm{mM}, 1 \mathrm{mM}$, and 10 $\mathrm{mM}$ concentrations, respectively. Each dissolved compound was stored at $4^{\circ} \mathrm{C}$ in the dark.

\section{Antibodies}

Anti-minichromosome maintenance (MCM2) antibody (Rabbit, \#2901-1), anti-cell division cycle 25 C (Cdc25C)

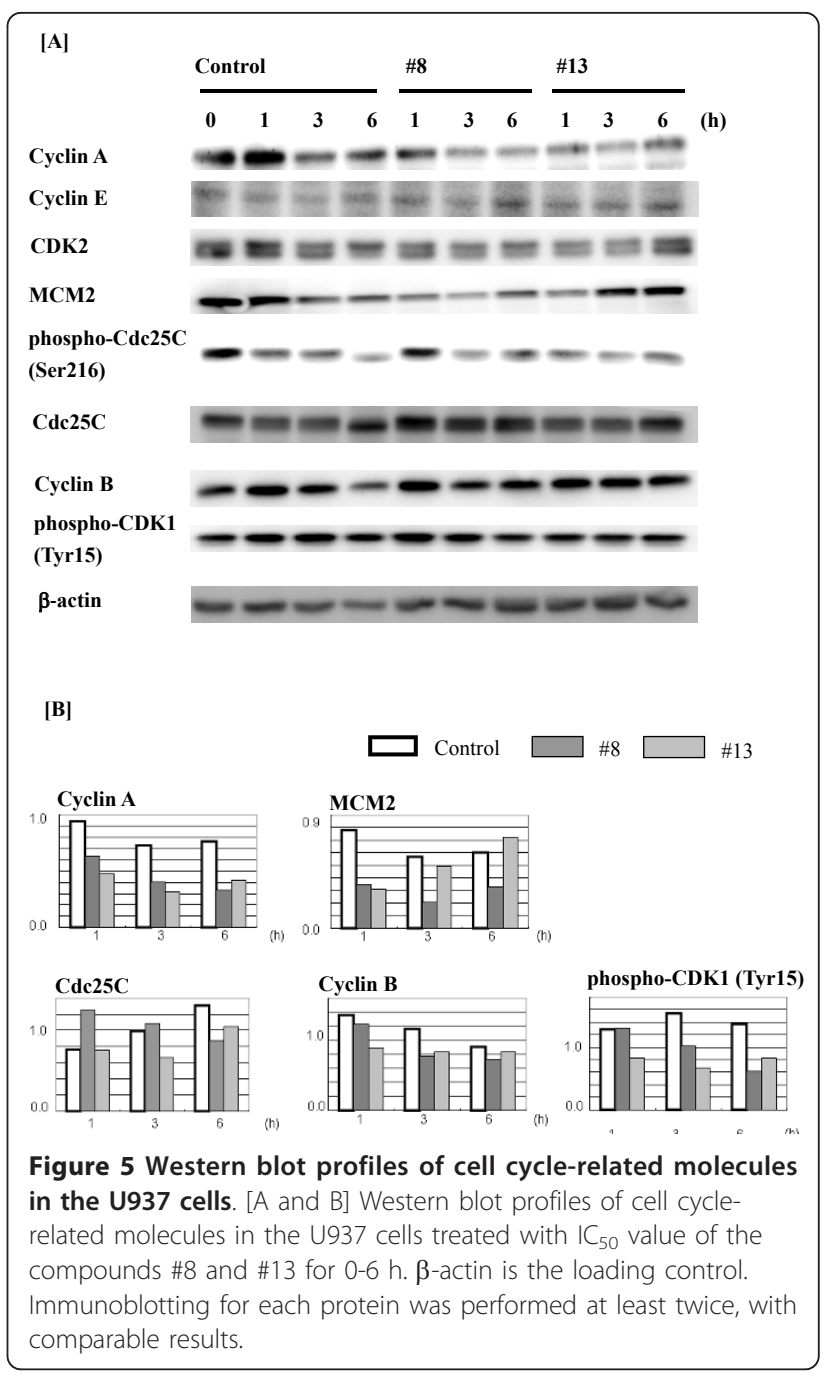

antibody (Rabbit, \#1302-1), and anti-phospho Cdc25C (Ser216) antibody (Rabbit, \#1190-1) were purchased from Epitomics Inc. (California, USA). Anti-actin antibody (Goat, C-11, sc-1615) and anti-cyclin dependent kinase 2 (CDK2) antibody (Rabbit, sc-163) were purchased from Santa Cruz Biotechnology (Santa Cruz, California, USA). Anti-cyclin E antibody (Mouse, \#4129), anti-cyclin A (BF683) antibody (Mouse, \#4656), anti-cyclin B1 (V152) antibody (Mouse, \#4135), and anti-phospho cdc2 (Tyr15) antibody (Rabbit, \#9111S) were purchased from Cell Signaling Technology (Tokyo, Japan).

\section{Cell line}

The U937 human leukemic monocyte lymphoma cell line was purchased from the RIKEN Bio-Resource Center (Tsukuba, Japan). This cell was maintained in continuous culture in RPMI1640 medium (Gibco ${ }^{\circledR}$, Invitrogen, California, USA) supplemented with $10 \%$ 
heat-inactivated fetal bovine serum (Bioserum, UBC, Japan) in a humidified atmosphere at $37^{\circ} \mathrm{C}$ and $5 \% \mathrm{CO}_{2}$.

\section{Cell growth inhibition assay}

In the first screening, the U937 cells were seeded in a 24-well tissue culture plate (Falcon, Becton Dickinson Biosciences, Franklin Lakes, USA) with $500 \mu$ of culture medium at a concentration of $5 \times 10^{4}$ cells/well, and each LC was added to the culture at a concentration of $10 \mu \mathrm{M}$. After $48 \mathrm{~h}$ incubation, cells at each condition were harvested, and diluted in trypan blue (Nacalai Tesque, Kyoto, Japan), which distinguishes viable cells from the damaged or dead ones. Cell growth was investigated by microscopy, and counting of viable cells was conducted using Burker-Turk hemocytometer (SLGC, Saitama, Japan). The relative value normalized to control values was calculated as the ratio of the number of LCtreated cells to the number of control cells. In the determination of $50 \%$ inhibitory concentration $\left(\mathrm{IC}_{50}\right)$, the U937 cells were seeded in a 48-well tissue culture plate (Falcon) with $200 \mu \mathrm{l}$ of culture medium at a concentration of $1 \times 10^{4}$ cells/well, and each LC was added to the culture at various concentrations ranging from 1.5 to 30 $\mu \mathrm{M}$. After $48 \mathrm{~h}$ incubation, cells at each condition were harvested, and the number of viable cells was counted by the trypan blue exclusion test under a microscope. The relative value normalized to control values was calculated as the ratio of the number of LC-treated cells to the number of control cells.

\section{Detection of apoptosis by flow cytometry}

The extent of apoptosis was determined by Annexin VFITC and propidium iodide (PI) staining according to the manufacturer's instructions. In brief, the cells were suspended with $100 \mu \mathrm{l}$ of binding buffer $(10 \mathrm{mM}$ HEPES/NaOH, $140 \mathrm{mM} \mathrm{NaCl}, 2.5 \mathrm{mM} \mathrm{CaCl}_{2}$; $\mathrm{pH} 7.4$ ) and stained with Annexin V-FITC for $10 \mathrm{~min}$ at room temperature in the dark. After washing with binding buffer, the cells were re-suspended in binding buffer containing PI $(20 \mu \mathrm{g} / \mathrm{ml})$. Apoptotic cells were determined using the Cell Lab Quanta ${ }^{\mathrm{TM}}$ SC MPL apparatus. In the Annexin V/PI quadrant gating, AnnexinV(-)/PI $(-)$, AnnexinV(-)/PI(+), AnnexinV(+)/PI(-), and Annexin $\mathrm{V}(+) / \mathrm{PI}(+)$ represented the fraction of viable cells, necrotic cells, early apoptotic cells, and late apoptotic/ secondary necrotic cells, respectively.

\section{Cell cycle analysis by flow cytometry}

The U937 cells were treated with each of the LCs in a tissue culture dish (Iwaki, Chiba, Japan), according to the method described above. After 3, 6, and $12 \mathrm{~h}$ of treatment, the harvested cells were treated with PBS containing $0.1 \%$ Triton X-100 (Wako) and stained with propidium iodide $(50 \mu \mathrm{g} / \mathrm{ml}$; Sigma). An analysis of the cell cycle distribution was performed using a flow cytometer (Quanta SC MPL; Beckman-Coulter, Fullerton, California, USA).

\section{SDS-PAGE and western blot analysis}

SDS-PAGE and western blot analysis were performed as described in previous reports [24]. Briefly, U937 cells were treated with each compound in the medium and incubated for the indicated times. The harvested cells were lysed with $50 \mathrm{mM}$ Hepes- $\mathrm{HCl}$ (pH 7.4), $100 \mathrm{mM}$ $\mathrm{NaCl}, 1 \%$ Triton $\mathrm{X}-100$, and $1 \mathrm{mM}$ PMSF (Wako) on ice for $30 \mathrm{~min}$, and sonicated twice for $30 \mathrm{~s}$ at ice-cold temperature. After centrifugation at 12,000 rpm for $20 \mathrm{~min}$ at $4{ }^{\circ} \mathrm{C}$, the protein concentration in the supernatant was determined with a Bio-Rad Protein Assay Kit (Bio-Rad Lab, Hercules, California, USA) using a SmartSpec ${ }^{\mathrm{TM}}$ Plus (Bio-Rad). Each protein lysate was mixed with $2 \times$ sample buffer $(625 \mathrm{mM}$ Tris-HCl, pH6.8, 20\% SDS, 2\% 2mercaptoethanol, 2\% glycerol). Each sample (30-50 $\mu \mathrm{g} /$ lane) was separated by SDS-PAGE after boiling for 5 min. Next, the proteins in the gel were transferred to a nitrocellulose membrane (Toyo Roshi, Tokyo, Japan). The membrane was reacted with each primary antibody in Tris-buffered saline $(10 \mathrm{mM}$ Tris- $\mathrm{HCl}, \mathrm{pH} 7.4,100$ $\mathrm{mM} \mathrm{NaCl}, 0.1 \%$ Tween-20), and supplemented with 5\% BSA or milk for $1 \mathrm{~h}$ at room temperature. After exposure to the primary antibody, membranes were labeled with donkey anti-rabbit IgG-HRP or anti-goat IgG-HRP antibody (Santa Cruz) or anti-mouse IgG-HRP antibody (R and D Systems, Minneapolis, USA) and the antigens were detected using ECL Plus Western Blotting Detection Reagents (GE Healthcare Japan, Tokyo, Japan).

\section{Statistical analysis}

The significance of the differences between the control and experimental groups were determined by Student's $t$-test or Mann-Whitney's $U$-test depending on the distribution. Statistically significant differences were defined as p-values of less than 0.05 .

\section{Abbreviations}

LCs: liquid-crystalline compounds.

\section{Acknowledgements}

This study was supported by a Grant-in-Aid for Challenging Exploratory Research from Japan Society for the Promotion of Science (No. 21655045, IK) and by a Grant for Hirosaki University Institutional Research (2009-2010).

\section{Author details}

'Department of Radiological Life Sciences, Hirosaki University Graduate School of Health Sciences, 66-1 Hon-cho, 036-8203, Aomori Hirosaki, Japan. ${ }^{2}$ Department of Frontier Materials Chemistry, Graduate School of Science and Technology, Hirosaki University, 3 Bunkyo-cho, Hirosaki 036-8561, Japan.

\section{Authors' contributions}

$\mathrm{JI}$ and $\mathrm{MH}$ were responsible for performing the majority of assays, discussing the study design and manuscript writing. YT and YF were responsible for 
performing a portion of the studies. AY was responsible for conceptualization of study ideas, study design, synthesization of liquid crystal compounds. IK was responsible for the entire project including conceptualization of study ideas, study design, evaluating results, study discussion, data analysis, manuscript writing and funding the study. All authors read and approved the final manuscript.

\section{Competing interests}

The authors declare that they have no competing interests.

Received: 19 August 2011 Accepted: 3 February 2012

Published: 3 February 2012

\section{References}

1. Kuo PL, Hsu YL, Lin TC, Chang JK: Induction of cell cycle arrest and apoptosis in human non-small cell lung cancer A549 cells by casuarinin from the bark of Terminalia arjuna Linn. Anticancer Drugs 2005, 16:409-415.

2. Abe A, Yamane M, Tomoda A: Prevention of growth of human lung carcinoma cells and induction of apoptosis by a novel phenoxazinone, 2-amino-4,4[alpha]-dihydro-4[alpha], 7-dimethyl-3H-phenoxazine-3-one. Anticancer Drugs 2001, 12:377-382.

3. Tang N, Du G, Wang N, Liu C, Hang H, Liang W: Improving penetration in tumors with nanoassemblies of phospholipids and doxorubicin. J Natl Cancer Inst 2007, 99:1004-1015.

4. Cheng JH, Hung CF, Yang SC, Wang JP, Won SJ, Lin CN: Synthesis and cytotoxic, anti-inflammatory, and anti-oxidant activities of 2', $5^{\prime}$ dialkoxylchalcones as cancer chemopreventive agents. Bioorg Med Chem 2008, 16:7270-7276.

5. Goel A, Prasad AK, Parmar VS, Ghosh B, Saini N: 7, 8-Dihydroxy-4methylcoumarin induces apoptosis of human lung adenocarcinoma cells by ROS-independent mitochondrial pathway through partial inhibition of ERK/MAPK signaling. FEBS Lett 2007, 581:2447-2454.

6. Chou TC, Zhang X, Zhong ZY, Li Y, Feng L, Eng S, Myles DR, Johnson R Jr, Wu N, Yin YI, Wilson RM, Danishefsky SJ: Therapeutic effect against human xenograft tumors in nude mice by the third generation microtubule stabilizing epothilones. Proc Natl Acad Sci USA 2008, 35:13157-13162.

7. Zhang JH, Fan CD, Zhao BX, Shin DS, Dong WL, Xie YS, Miao JY: Synthesis and preliminary biological evaluation of novel pyrazolo[1,5-a] pyrazin-4 (5H)-one derivatives aspotential agents against A549 lung cancer cells. Bioorg Med Chem 2008, 16:10165-10171.

8. Takahashi Y, Hazawa M, Takahashi K, Nishizawa A, Yoshizawa A, Kashiwakura I: Suppressive effects of liquid crystal compounds on the growth of the A549 human lung cancer cell line. Invest New Drugs 2010 29:659-665.

9. Ysoshizawa A, Takahashi Y, Nishizawa A, Takeuchi K, Sagishita M, Takahashi K, Hazawa M, Kashiwakura I: Biological activity of some cyanobiphenyl derivatives. Chem Lett 2009, 38:530-531.

10. Vermes I, Haanen C, Steffens-Nakken H, Reutelingsperger C: A novel assay for apoptosis Flow cytometric detection of phosphatidylserine expression on early apoptotic cells using fluorescein labeled Annexin V. J Immunol Methods 1995, 184:39-51.

11. Hazawa M, Takahashi K, Wada K, Kawahara N, Kashiwakura I: Structureactivity relationships between the Aconitum $\mathrm{C}_{20}$-diterpenoid alkaloid derivatives and the growth suppressive activities of non-Hodgkin's lymphoma Raji cells and human hematopoietic stem/progenitor cells. Invest New Drugs 2011, 29:1-8.

12. Lundberg AS, Weinberg RA: Functional inactivation of the retinoblastoma protein requires sequential modification by at least two distinct cyclincdk complexes. Mol Cell Biol 1998, 18:753-761.

13. Ewen ME: Where the cell cycle and histones meet. Genes Dev 2000, 14:2265-2270

14. Treisman JE, Follette PJ, O'Farrell PH, Rubin GM: Cell proliferation and DNA replication defects in a Drosophila MCM2 mutant. Genes Dev 1995, 9:1709-1715.

15. Todorov IT, Pepperkok R, Philipova RN, Kearsey SE, Ansorge W, Werner D: A human nuclear protein with sequence homology to a family of early $S$ phase proteins is required for entry into $S$ phase and for cell division. $J$ Cell Sci 1994, 107:253-265.

16. Pagano M, Pepperkok R, Verde F, Ansorge W, Draetta G: Cyclin A is required at two points in the human cell cycle. EMBO J 1992, 11:961-971.
17. Atherton-Fessler S, Parker LL, Geahlen RL, Piwnica-Worms H: Mechanisms of p34cdc2 regulation. Mol Cell Biol 1993, 13:1675-1685.

18. Norbury C, Blow J, Nurse P: Regulatory phosphorylation of the p34cdc2 protein kinase in vertebrates. EMBO J 1991, 10:3321-3329.

19. Zhang C, Fan X, Xu X, Yang X, Wang X, Liang HP: Evodiamine induces caspase-dependent apoptosis and $\mathrm{S}$ phase arrest in human colon lovo cells. Anticancer Drugs 2010, 21:766-776.

20. Giard DJ, Aaronson SA, Todaro GJ, Amstein P, Kersey JH, Dosik H, Parks WP: In vitro cultivation of human tumors: establishment of cell lines derived from a series of solid tumors. J Natl Cancer Inst 1973, 51:1417-1423.

21. Sugimoto K, Toyoshima H, Sakai R, Miyagawa K, Hagiwara K, Ishikawa F, Takaku F, Yazaki Y, Hirai H: Frequent mutations in the p53 gene in human myeloid leukemia cell lines. Blood 1992, 79:2378-2383.

22. O'Connor PM, Jackman J, Bae I, Myers TG, Fan S, Mutoh M, Scudiero DA, Monks A, Sausville EA, Weinstein JN, Friend S, Fornace AJ Jr, Kohn KW: Characterization of the $\mathrm{p} 53$ tumor suppressor pathway in cell lines of the National Cancer Institute anticancer drug screen and correlations with the growth-inhibitory potency of 123 anticancer agents. Cancer Res 1997, 57:4285-4300.

23. Takahashi Y, Hazawa M, Takahashi K, Sagisaka M, Kashiwakura I, Yoshizawa A: Supramolecular assembly composed of different mesogenic compounds possessing a w-hydroxyalkyl unit exhibits suppressive effects on the A549 human lung cancer cell line. Med Chem Comm 2011, 2:55-59.

24. Hosseinimehr JS, Inanami O, Hamasu T, Takahashi M, Kashiwakura I, Asanuma T, Kuwabara M: Activation of c-kit by stem cell factor induces radioresistance to apoptosis through ERK-dependent expression of survivin in HL60 cells. J Radiat Res 2004, 45:557-561.

doi:10.1186/1475-2867-12-3

Cite this article as: Ishikawa et al:: Suppressive effects of liquid crystal compounds on the growth of U937 human leukemic monocyte lymphoma cells. Cancer Cell International 2012 12:3.

\section{Submit your next manuscript to BioMed Central and take full advantage of:}

- Convenient online submission

- Thorough peer review

- No space constraints or color figure charges

- Immediate publication on acceptance

- Inclusion in PubMed, CAS, Scopus and Google Scholar

- Research which is freely available for redistribution

Submit your manuscript at www.biomedcentral.com/submit
C Biomed Central 